\title{
Green Tea-Derived Epigallocatechin Gallate Inhibits Acid Production and Promotes the Aggregation of Streptococcus mutans and Non-Mutans Streptococci
}

\author{
Sili Han ${ }^{a, b}$ Yuki Abiko $^{a}$ Jumpei Washio $^{a}$ Yufang Luo ${ }^{a, c}$ Linglin Zhang ${ }^{b}$ \\ Nobuhiro Takahashi ${ }^{a}$ \\ ${ }^{a}$ Division of Oral Ecology and Biochemistry, Tohoku University Graduate School of Dentistry, Sendai, Japan; \\ ${ }^{b}$ Department of Cariology and Endodontics, Sichuan University West China School of Stomatology, Chengdu, \\ China; 'Department of Cariology and Endodontics, Fujian Medical University School of Stomatology, Fuzhou, China
}

\section{Keywords \\ Epigallocatechin gallate $\cdot$ Dental caries $\cdot$ Streptococcus mutans - Non-mutans streptococci · Acid production . Bacterial aggregation}

\begin{abstract}
It has been suggested that green tea-derived epigallocatechin gallate (EGCG), which has antimicrobial properties, might help prevent dental caries. However, the detailed properties of EGCG remain unclear. In this study, the antimicrobial properties of EGCG were evaluated by examining its bactericidal activity, its inhibitory effects against bacterial growth, acid production, acidic end-product formation, and sugar uptake (phosphoenolpyruvate-dependent phosphotransferase system, PEP-PTS activity), and its effects on bacterial aggregation, using monocultured planktonic cells of Streptococcus mutans and non-mutans streptococci. Coincubating S. mutans with EGCG $(1 \mathrm{mg} / \mathrm{mL})$ for $4 \mathrm{~h}$ had no bactericidal effects, while it decreased the growth and acid production of $S$. mutans by inhibiting the activity of the PEP-PTS. EGCG ( $2 \mathrm{mg} / \mathrm{mL}$ ) caused rapid bacterial cell aggregation and had reduced the optical density of $S$. mutans cell suspension by $86.7 \%$ at $\mathrm{pH} 7.0$ and $90.7 \%$ at $\mathrm{pH} 5.5$ after 2 h. EGCG also
\end{abstract}

reduced the acid production of non-mutans streptococci, including S. sanguinis, S. gordonii, and S. salivarius, and promoted the aggregation of these non-mutans streptococci. Furthermore, these antimicrobial effects of short-term EGCG treatment persisted in the presence of saliva. These results suggest that EGCG might have short-term antibacterial effects on caries-associated streptococci in the oral cavity.

(c) 2021 The Author(s)

Published by S. Karger AG, Basel

\section{Introduction}

Although many antibacterial medicines have been suggested to be useful for preventing caries, they eliminate most bacteria in the oral cavity, resulting in the destruction of normal or health-related oral flora, leading to several defects in the oral ecosystem, including the emergence of resistant strains and opportunistic infections [Segura-Egea et al., 2017]. Thus, as an antibacterial strategy aimed at preventing caries, it would be more effective to target bacterial cariogenic factors without threatening the presence of indigenous bacterial species in the oral ecosystem [Nyvad and Takahashi, 2020]. This approach
C 2021 The Author(s)

Published by S. Karger AG, Basel

This is an Open Access article licensed under the Creative Commons Attribution-NonCommercial-4.0 International License (CC BY-NC) (http://www.karger.com/Services/OpenAccessLicense), applicable to the online version of the article only. Usage and distribution for commercial purposes requires written permission.
Correspondence to:

Nobuhiro Takahashi,nobuhiro.takahashi.a5@tohoku.ac.jp 
is now being widely investigated since it could suppress carbohydrate metabolism (acid production) and biofilm formation without stimulating the emergence of resistant bacteria.

Diet is a key factor influencing oral health. Many studies have focused on food or additives with oral health functions. Green tea (a Camellia sinensis dry leaf infusion) is one of the most popular beverages in the world, and it is known to be a rich source of polyphenols [Wang and Ho, 2009]. Clinical trials have demonstrated that drinking tea (without added sugar) is associated with lower caries levels in humans [Hamilton-Miller, 2001]. In addition, mouthwash with green tea (1.6 g green tea in 40 $\mathrm{mL}$ distilled water, 3 times per day for 1 week) significantly reduced the salivary levels of the virulent cariogenic pathogens Streptococcus mutans and lactobacilli [Ferrazzano et al., 2011]. Although tea is also a source of fluoride, many studies have demonstrated that the polyphenols in tea, rather than its fluoride content, are the main contributors to its anticariogenic potential [Yu et al., 1995]. Tea-derived polyphenolic components have been reported to exhibit a wide range of biological properties, such as antioxidant, antimicrobial, anti-inflammatory, and cancer-preventive effects [Singh et al., 2011; Reygaert, 2014].

Four polyphenols are the major polyphenols in green tea, (-)-epicatechin, (-)-epigallocatechin, (-)-epigallocatechin-3-gallate (EGCG), and (-)-epicatechin-3-gallate. EGCG is the most common polyphenol in green tea, accounting for $>50 \%$ of all green tea components, followed by epigallocatechin and epicatechin-3-gallate [Wang and Ho, 2009]. EGCG also exhibits the strongest antimicrobial activity of all catechins [Sasaki et al., 2004]. It is demonstrated that EGCG inhibits the glycosyltransferase (GTF) activity of $S$. mutans, as well as various cariogenic virulence factors of $S$. mutans at the transcriptional and enzymatic levels [Xu et al., 2011]. In addition, catechins can bind to bacterial cell membranes, especially in Gram-positive bacteria. This phenomenon might lead to interference with, and even damage to, bacterial membranes and hinder adhesion [Ikigai et al., 1993]. As well as inhibiting GTF activity, EGCG is able to significantly suppress $S$. mutans-induced biofilm formation [Hengge, 2019; Xu et al., 2012]. EGCG has also been reported to suppress the sucrose-induced acid production of $S$. $m u$ tans, and rinsing with $2 \mathrm{mg} / \mathrm{mL}$ EGCG solution reduced the in situ acidity of dental plaque [Hirasawa et al., 2006]. In the latter study, the viability of $S$. mutans in a sucrosecontaining culture and that of $S$. mutans that had adhered to hydroxyapatite was not affected by the examined con- centrations of EGCG, indicating that other mechanisms besides bactericidal activity might have contributed to the observed inhibition of acid production. Moreover, the presence of protein components in complex media significantly affected the antimicrobial activity of polyphenolic compounds, suggesting that factors found in the oral environment might influence the effects of EGCG [Xu et al., 2018]. However, these antimicrobial properties of EGCG have not been characterized in detail, especially the effects of EGCG on the main virulence factors responsible for dental caries, sugar-induced acid production and the adhesion/aggregation of non-mutans streptococci as well as mutans streptococci. Therefore, the present study aimed to characterize the effects of EGCG against the monocultured planktonic cells of mutans streptococci and non-mutans streptococci by examining its bactericidal activity, its inhibitory activity against bacterial acidogenicity and sugar uptake, its effects on bacterial aggregation, and the effect of saliva on these effects.

\section{Materials and Methods}

Green Tea-Derived Catechins, Bacterial Strains, and Growth Conditions

EGCG isolated from green tea was purchased from Funakoshi (Funakoshi, Tokyo, Japan). Representative caries-associated bacterial species, including S. mutans NCTC 10449 as a mutans streptococcus, and S. sanguinis JCM 5708, S. gordonii JCM 12995, and S. salivarius JCM 5707 as non-mutans streptococci, were used in this study. The bacteria were grown at $37^{\circ} \mathrm{C}$ for 2 days on blood agar plates in an anaerobic glove box $\left(\mathrm{N}_{2}, 80 \% ; \mathrm{H}_{2}, 10 \% ; \mathrm{CO}_{2}, 10 \%\right.$; NHC type; Hirasawa Works, Tokyo, Japan) and maintained in anaerobic conditions at $4^{\circ} \mathrm{C}$. The bacteria were precultured anaerobically at $37^{\circ} \mathrm{C}$ overnight in a complex medium containing $1.7 \%$ tryptone (Becton Dickinson, Franklin Lakes, NJ, USA), 0.3\% yeast extract (Becton Dickinson), $0.5 \% \mathrm{NaCl}, 50 \mathrm{mmol} / \mathrm{L}$ potassium phosphate buffer solution (PPB, pH 7.0), and 0.5\% glucose (TYG medium). The bacterial culture was transferred to TYG medium (final concentration: $5 \%$ ) and grown in the same conditions. In the logarithmic growth phase (optical density [OD] at $660 \mathrm{~nm}: 0.8-$ $0.9)$, the bacterial cells were harvested by centrifugation $(21,000 \mathrm{~g}$, $7 \mathrm{~min}, 4^{\circ} \mathrm{C}$ ) in double-sealed centrifuge tubes to maintain anaerobic conditions. Then, they were washed with washing buffer $(2$ $\mathrm{mmol} / \mathrm{L} \mathrm{PPB}$ containing $150 \mathrm{mmol} / \mathrm{L} \mathrm{KCl}$ and $5 \mathrm{mmol} / \mathrm{L} \mathrm{MgCl}_{2}$, $\mathrm{pH}$ 7.0) before being used. During sugar metabolism, bacteria rapidly consume oxygen and create anaerobic conditions even in the shallow layer of oral biofilms. To mimic this environment, we conducted growth, viability, and $\mathrm{pH}$-stat experiments under anaerobic conditions.

Effects of EGCG on the Growth and Viability of S. mutans

Four milliliters of TYG medium were inoculated with $0.1 \mathrm{~mL}$ of overnight culture of $S$. mutans. EGCG was then added to the TYG culture at final concentrations of $0.5,1$, and $2 \mathrm{mg} / \mathrm{L}$. The control contained S. mutans grown in the absence of EGCG. The cul- 
tures were incubated anaerobically in the NHC-type anaerobic glove box at $37^{\circ} \mathrm{C}$ for $24 \mathrm{~h}$. Absorbance at $660 \mathrm{~nm}$ was monitored during the growth process.

S. mutans $\left(1 \times 10^{6}\right.$ colony-forming units $\left./ \mathrm{mL}\right)$ were incubated with EGCG $(0.5-2 \mathrm{mg} / \mathrm{mL})$ in washing buffer at $37^{\circ} \mathrm{C}$ in the NHCtype anaerobic glove box. Sterile deionized water was added as a control. Cell samples were removed at $0,0.5,1,2$, and $4 \mathrm{~h}$, serially diluted in the same buffer, and plated onto TYG agar plates. All plates were incubated anaerobically at $37^{\circ} \mathrm{C}$ for $48 \mathrm{~h}$, and the number of colonies was then counted. Time-killing curves showing colony-forming units per milliliter versus time were plotted. The experiments were repeated 3 times independently.

Effects of EGCG on the Acid Production of S. mutans and NonMutans Streptococci

To avoid the influence of $\mathrm{CO}_{2}$, which is dissolved in aqueous solution and causes acidification, all experiments on the bacterial acid production were performed in the $\mathrm{NH}$-type anaerobic glove box $\left(\mathrm{N}_{2}, 90 \% ; \mathrm{H}_{2}, 10 \%\right.$; NH-type; Hirasawa Works, Tokyo, Japan). S. mutans, S. sanguinis, S. gordonii, and S. salivarius were suspended in washing buffer and stored at $4^{\circ} \mathrm{C}$ until use. Each reaction mixture $(2.9 \mathrm{~mL})$ contained bacterial cells $\left(\mathrm{OD}_{660 \mathrm{~nm}}=0.5\right)$, EGCG $(0.5,1$, or $2 \mathrm{mg} / \mathrm{mL}), 2 \mathrm{mmol} / \mathrm{L} \mathrm{PPB}, 150 \mathrm{mmol} / \mathrm{L} \mathrm{KCl}$, and $5 \mathrm{mmol} / \mathrm{L} \mathrm{MgCl}_{2}$. The control mixture did not contain EGCG. After being subjected to 5 -min preincubation at $37^{\circ} \mathrm{C}$, the cell suspension was incubated with EGCG for a further $3 \mathrm{~min}$. Then, $0.1 \mathrm{~mL}$ glucose was added to the reaction mixture at a final concentration of $10 \mathrm{mmol} / \mathrm{L}$, and acid production was monitored for 10 min using a pH-stat system (AUTO pH STAT, model AUT211S; TOA Electronics, Tokyo, Japan). The experiments were carried out at $\mathrm{pH} 7.0$ and $\mathrm{pH}$ 5.5. The $\mathrm{pH}$ was adjusted to 5.5 by adding $10-20 \mu \mathrm{L}$ of $0.12 \mathrm{~mol} / \mathrm{L} \mathrm{HCl}$ to the reaction mixture according to previous research [Manome et al., 2019]. When the $\mathrm{pH}$ of the reaction mixture began to fall due to acid production by the cells, $0.025 \mathrm{~mol} / \mathrm{L} \mathrm{KOH}$ was automatically added to the mixture to maintain the predetermined $\mathrm{pH}$, and the amount of $\mathrm{KOH}$ added was monitored to estimate the amount of acid production [Manome et al., 2019].

For $S$. mutans, a pH reduction experiment was also conducted. The reaction mixture contained $S$. mutans $\left(\mathrm{OD}_{660 \mathrm{~nm}}=0.5\right)$, EGCG $(0.5,1$, or $2 \mathrm{mg} / \mathrm{mL}), 0.5 \mathrm{mmol} / \mathrm{L}$ potassium phosphate buffer (pH 7.0), $37.5 \mathrm{mmol} / \mathrm{L} \mathrm{KCl}$, and $1.25 \mathrm{mmol} / \mathrm{L} \mathrm{MgCl}_{2}$. The control mixture did not contain EGCG. After glucose had been added to the mixture at the final concentration of $10 \mathrm{mmol} / \mathrm{L}$, the reduction in $\mathrm{pH}$ was monitored for $1 \mathrm{~h}$ in the $\mathrm{NH}$-type anaerobic glove box.

A titration curve of $1 \mathrm{mg} / \mathrm{mL}$ EGCG $(2 \mathrm{~mL})$ from $\mathrm{pH} 7.5$ to 4.5 was generated with $10 \mathrm{mmol} / \mathrm{L}$ hydrochloric acid, and the buffering capacity $(\beta)$ of EGCG solution was calculated using the equation: $\beta=\Delta \mathrm{a} / \Delta \mathrm{pH}$, where $\Delta \mathrm{a}$ is the amount of added acid, and $\Delta \mathrm{pH}$ is the reduced amount of $\mathrm{pH}$ value.

\section{Analysis of Acidic End-Product Production}

The reaction mixture $(0.45 \mathrm{~mL})$ used to examine glucose metabolism in the pH-stat assay was sampled before and after the addition of glucose. These samples were immediately mixed with $0.05 \mathrm{~mL}$ of $6 \mathrm{~mol} / \mathrm{L}$ perchloric acid and filtered through a polypropylene membrane (pore size: $0.20 \mathrm{~mm}$; Toyo Roshi Ltd., Tokyo, Japan). The concentrations of acidic end-products, including a-ketoglutarate, citric acid, pyruvate, malic acid, succinic acid, fu- maric acid, lactate, formate, and acetate, were quantitatively analyzed by high-performance liquid chromatography (HPLC; Shimadzu Prominence LC-20AD, Shimadzu Co. Ltd., Kyoto, Japan), as described in previous studies [Takahashi et al., 1987; Norimatsu et al., 2015]. Using the data obtained in the $\mathrm{pH}$-stat assay and HPLC analysis, the $50 \%$ inhibitory concentration $\left(\mathrm{IC}_{50}\right)$ of EGCG was calculated respectively, based on the following equation: $\mathrm{IC}_{50}=10^{\wedge}(\log [\mathrm{A} / \mathrm{B}] \times[50-\mathrm{C}] /[\mathrm{C}-\mathrm{D}]+\log [\mathrm{B}])$, where $\mathrm{A}$ is a higher concentration than $50 \%, \mathrm{~B}$ is a lower concentration than $50 \%, \mathrm{C}$ is the inhibition rate (\%) at $\mathrm{B}$, and $\mathrm{D}$ is the inhibition rate (\%) at A.

\section{Phosphoenolpyruvate-Dependent Phosphotransferase System} Activity

$S$. mutans cell suspension $\left(\mathrm{OD}_{660 \mathrm{~nm}}=0.5\right)$, which was prepared as described above, was treated with $0-2 \mathrm{mg} / \mathrm{mL}$ EGCG or washing buffer for $15 \mathrm{~min}$ and washed twice, before the treated cells were collected by centrifugation. The phosphoenolpyruvate-dependent phosphotransferase system (PEP-PTS) activity of S. mutans was estimated according to the method of Iwami and Yamada [1985]. To measure the PEP-PTS activity, the EGCG/washing buffertreated cells were suspended in $40 \mathrm{mmol} / \mathrm{L}$ potassium phosphate buffer ( $\mathrm{pH} 7.0$ ) containing $5 \mathrm{mmol} / \mathrm{L} \mathrm{MgCl}_{2}$. The suspension was then treated with a 0.05 volume of toluene-acetone (1:4) and mixed vigorously to permeabilize the cells. The assay mixture contained $10 \mathrm{mmol} / \mathrm{L} \mathrm{MgCl}_{2}, 1 \mathrm{mmol} / \mathrm{L} \mathrm{NADP}, 1 \mathrm{mmol} / \mathrm{L}$ phosphoenolpyruvate, $1 \mathrm{mmol} / \mathrm{L}$ glucose, $2.1 \mathrm{U} / \mathrm{mL}$ glucose- 6 -phosphate dehydrogenase (from yeast; Roche Diagnostics, Mannheim, Germany), and permeabilized cells in $100 \mathrm{mmol} / \mathrm{L}$ Tris- $\mathrm{HCl}$ buffer ( $\mathrm{pH}$ 7.6). The increase in the concentration of NADPH was monitored spectrophotometrically at $340 \mathrm{~nm}$ and used to estimate PEP-PTS activity (Fig. 4a).

\section{Bacterial Aggregation Measurement}

Cell suspensions of S. mutans, S. sanguinis, S. gordonii, or $S$. salivarius $\left(\mathrm{OD}_{660 \mathrm{~nm}}=2.0\right)$ were prepared as described above. Each cell suspension $(1.5 \mathrm{~mL})$ was mixed with EGCG solution in washing buffer $(1.5 \mathrm{~mL})$ in a test tube and incubated at $37^{\circ} \mathrm{C}$ for $1 \mathrm{~h}$. The absorbance of the mixture at $660 \mathrm{~nm}$ was examined at 10 -min intervals. The bacterial aggregation rate was calculated using the following equation: aggregation rate $(\%)=100 \times($ initial OD - final OD)/initial OD.

\section{The Effects of Saliva on the Properties of EGCG}

Human stimulated saliva was obtained from 5 healthy volunteers, who were free from oral disease, after they had chewed paraffin. The saliva samples were mixed in a test tube and sterilized using a $0.22-\mu \mathrm{m}$ membrane filter. To evaluate the effects of saliva, EGCG was diluted in the stimulated saliva. Then, the glucose-induced reduction in $\mathrm{pH}$ and bacterial aggregation were examined using the EGCG dissolved in saliva.

\section{Statistical Analyses}

The significance of intergroup differences was evaluated using the Student paired $t$ test. Differences among 3 or more groups were assessed for significance using one-way analysis of variance and Tukey's multiple comparisons test. $p$ values of $<0.05$ were considered statistically significant. The data of $\mathrm{IC}_{50}$ are shown as means and $95 \%$ confidence intervals. The other data are presented as means \pm SD values. 


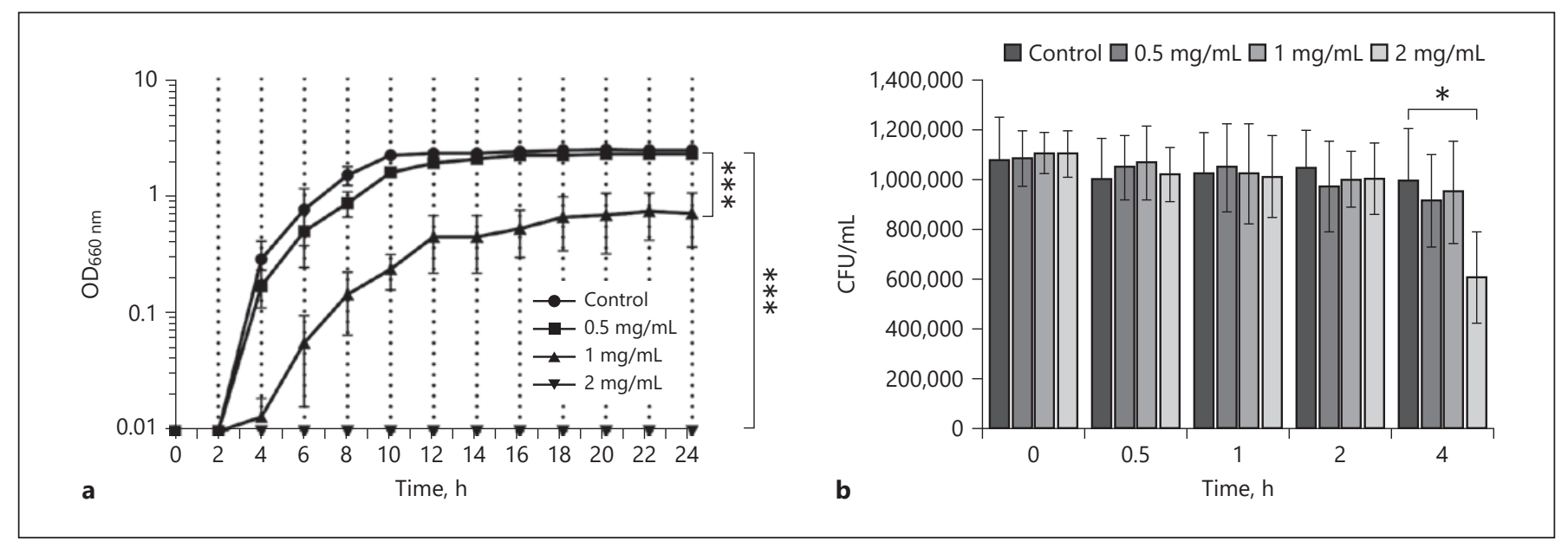

Fig. 1. Effects of EGCG on the growth of $S$. mutans (a) and the kinetic killing effects of EGCG on S. mutans (b). *** $p<0.001, * p<0.05$. OD, optical density; CFU, colony-forming units.

\section{Results}

\section{Effects of EGCG on the Growth and Viability of S.} mutans

EGCG inhibited the growth of $S$. mutans in TYG medium in a dose-dependent manner (Fig. 1a). In the presence of $2 \mathrm{mg} / \mathrm{mL}$ EGCG, $S$. mutans could not grow in TYG medium. In the presence of 1 or $0.5 \mathrm{mg} / \mathrm{mL}$ EGCG, the growth of $S$. mutans was limited and slowed down, respectively.

EGCG (up to $2 \mathrm{mg} / \mathrm{mL}$ ) had no significant effect on the viability of $S$. mutans over a 2 -h coincubation period (Fig. 1b). However, coincubating S. mutans with $2 \mathrm{mg} /$ $\mathrm{mL}$ EGCG for $4 \mathrm{~h}$ reduced the number of viable bacteria by $40 \%$.

Effects of EGCG on the Acid Production of S. mutans

Based on the titration volume of $\mathrm{KOH}$ solution, bacterial acid production was monitored in real time using the pH-stat assay (Fig. 2a, b). The rate of bacterial acid production was markedly inhibited by EGCG at both $\mathrm{pH} 7.0$ and 5.5. A high concentration of EGCG $(2 \mathrm{mg} / \mathrm{mL})$ decreased the acid production of S. mutans by $94 \%$ at $\mathrm{pH} 7.0$ and by $96 \%$ at $\mathrm{pH} 5.5$.

The production of acidic end-products was also quantified using HPLC (Fig. 2c, d). All of the examined bacteria produced lactate, formate, and acetate and exhibited similar acidic end-product profiles. The levels of acidic end-products decreased as the concentration of EGCG increased. The $\mathrm{IC}_{50}$ of EGCG for $S$. mutans acid production was $0.69 \mathrm{mg} / \mathrm{mL}$ at $\mathrm{pH} 7.0$ and $0.80 \mathrm{mg} / \mathrm{mL}$ at $\mathrm{pH} 5.5$ as the results of $\mathrm{pH}$-stat, and $0.69 \mathrm{mg} / \mathrm{mL}$ at $\mathrm{pH} 7.0$ and $0.71 \mathrm{mg} / \mathrm{mL}$ at $\mathrm{pH} 5.5$ as the result of HPLC. There was no significant difference between the results of acid production assay and acidic end-product quantification.

Similarly, EGCG significantly suppressed the glucoseinduced reduction in $\mathrm{pH}$ (Fig. 3a). The $\mathrm{pH}$ remained above pH 5.5 in all EGCG-treated groups. The manner in which the $\mathrm{pH}$ value from $\mathrm{pH} 7.0$ after the addition of $\mathrm{HCl}$ to the EGCG solution revealed that EGCG also possesses buffer capacity, which reduced with the $\mathrm{pH}$ decrease (Fig. 3b).

Effects of EGCG on the PEP-PTS Activity of S. mutans

Since EGCG is a large molecule and is known to be able to bind to bacterial membranes, it is theoretically possible that EGCG can inhibit the cell-membrane-associated enzymes involved in sugar metabolism. Thus, the activity of the PEP-PTS, an enzymatic sugar uptake system, was examined. After the addition of EGCG, the PEP-PTS activity of S. $m u$ tans decreased as the concentration of EGCG increased (Fig. 4b). The extent of the inhibition of the enzymatic activity seemed to correspond to the amount of acid production by S. mutans according to the $\mathrm{pH}$-stat assay (Fig. 2).

\section{EGCG Promoted the Aggregation of S. mutans}

Measuring absorbance at $660 \mathrm{~nm}$ allowed the amount of bacterial aggregation to be quantified. EGCG treatment resulted in lower absorbance values due to greater cell aggregation and a reduction in the number of bacteria dispersed in the buffer. Figure 5 shows that the addition of $2 \mathrm{mg} / \mathrm{mL}$ EGCG resulted in a rapid reduction in absorbance at $660 \mathrm{~nm}$. Over $120 \mathrm{~min}, 2 \mathrm{mg} / \mathrm{mL}$ EGCG in- 


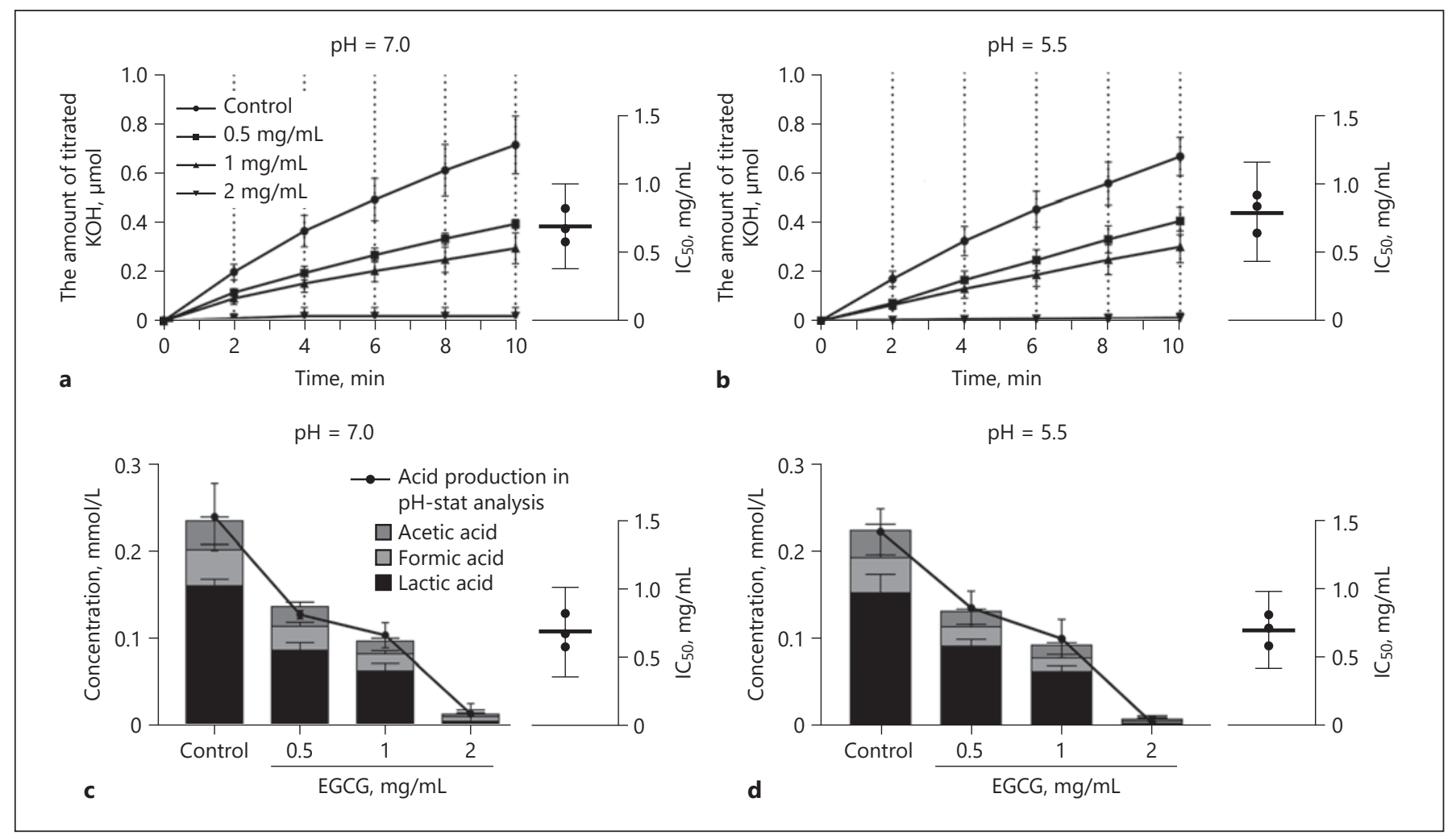

Fig. 2. Effects of EGCG on acid production at $\mathrm{pH} 7.0$ (a) and $\mathrm{pH} 5.5$ (b) and on acidic end-product levels at $\mathrm{pH}$ 7.0 (c) and pH 5.5 (d) in S. mutans. IC I0 $_{50}$ EGCG on S. mutans acid production and its $95 \%$ confidence interval calculated from both $\mathrm{pH}$-stat assay and HPLC analysis are shown, respectively.

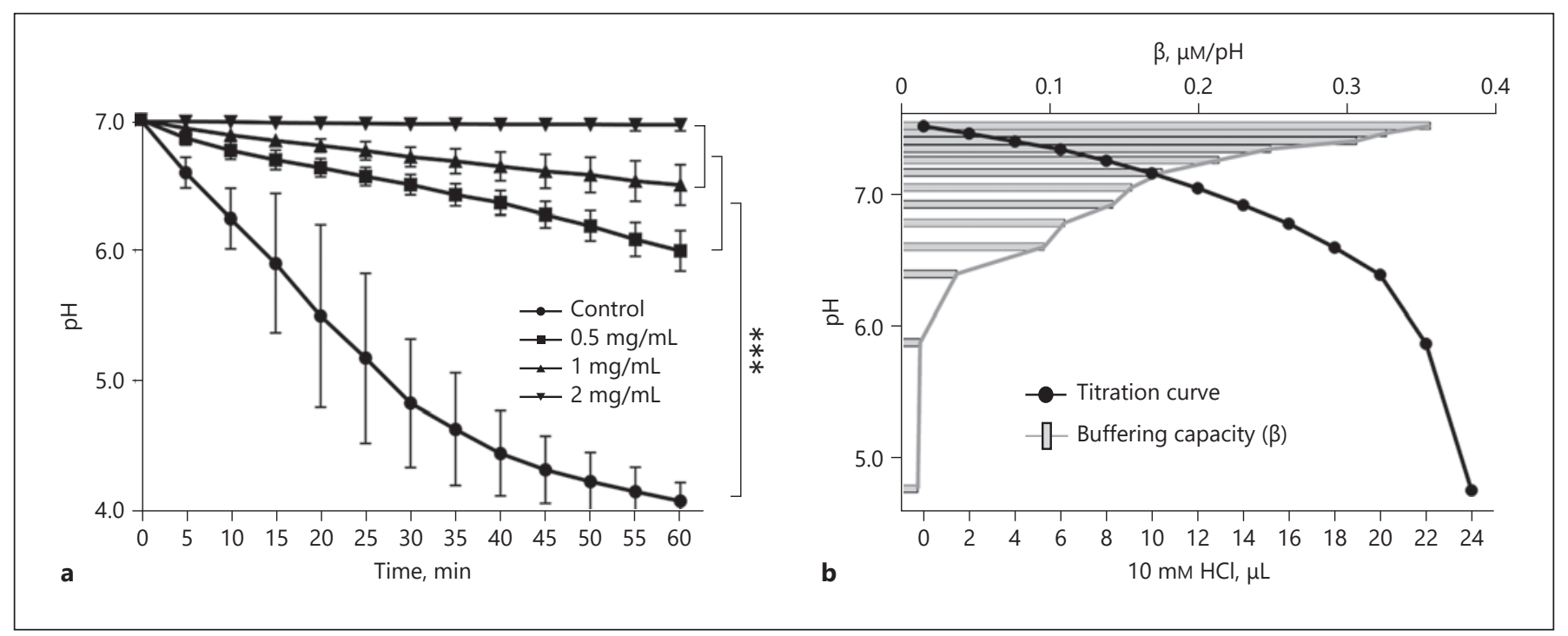

Fig. 3. Effects of EGCG on the glucose-induced pH reduction caused by $S$. mutans (a) and the acid-buffering capacity of EGCG solution (b). ${ }^{* * *} p<0.001$. 

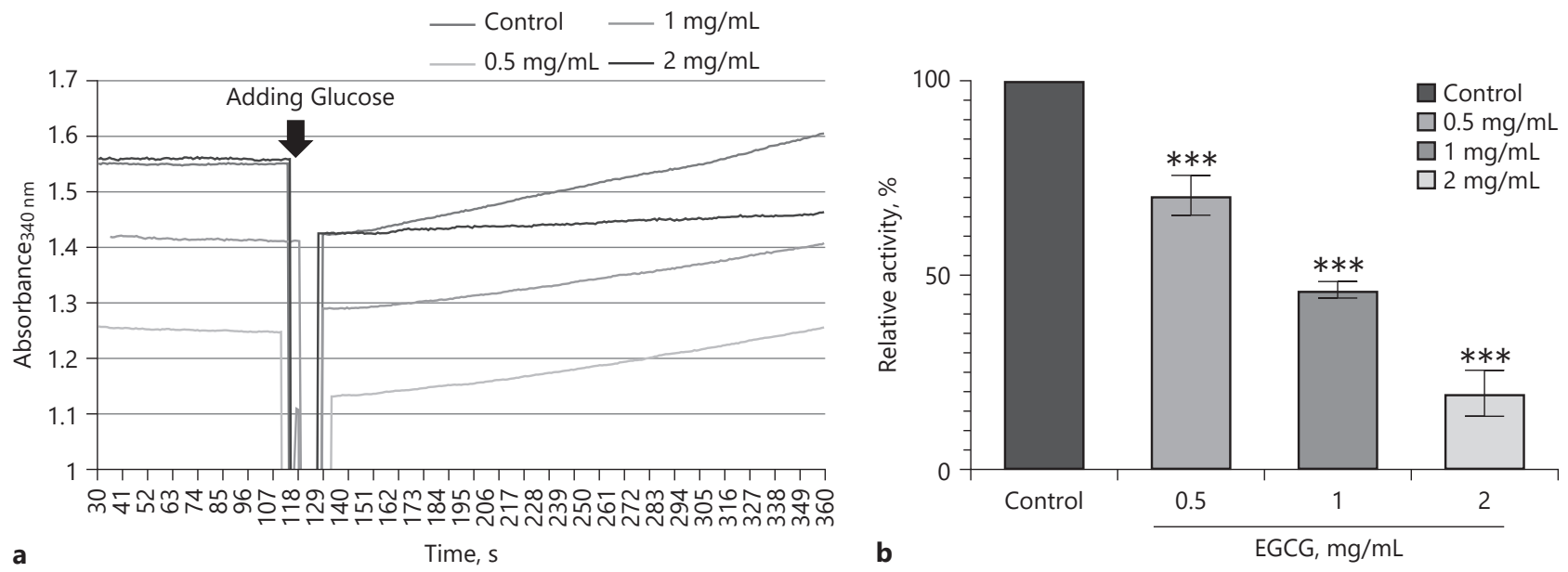

Fig. 4. Measurement of PEP-PTS activity by monitoring the increase in the concentration of NADPH spectrophotometrically at $340 \mathrm{~nm}$ (a) and inhibition of PEP-PTS activity by EGCG (b). ${ }^{* * *} p<0.001$.

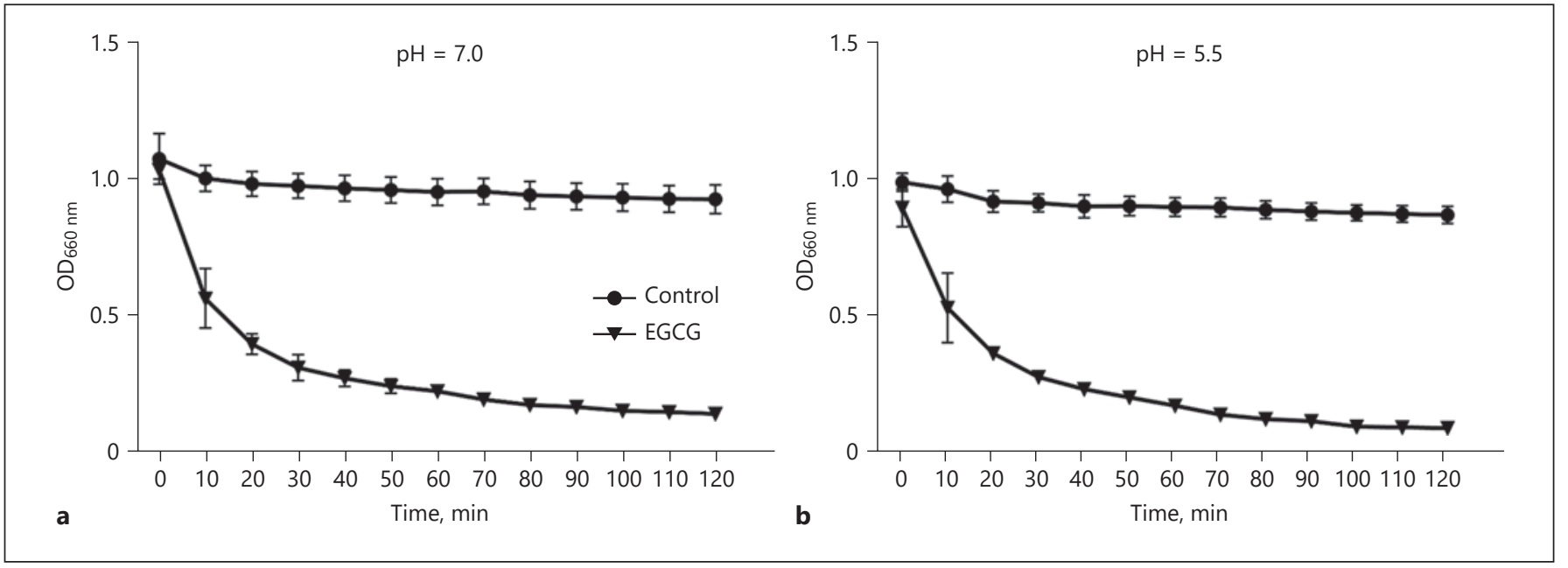

Fig. 5. Optical density (OD) at $660 \mathrm{~nm}$ of an $S$. mutans cell suspension after the addition of EGCG at pH 7.0 (a) or $\mathrm{pH} 5.5$ (b). The data in the curves are means \pm SD values.

creased bacterial aggregation in the cell suspension by $86.7 \%$ at $\mathrm{pH} 7.0$ and $90.7 \%$ at $\mathrm{pH} 5.5$.

\section{Effects of EGCG on the Glucose-Induced Acid}

Production and Aggregation of Non-Mutans

Streptococcus Strains

EGCG also had a marked inhibitory effect on the acid production of S. sanguinis, S. gordonii, and S. salivarius (Table 1). Among the 4 streptococcal strains, S. gordonii was less sensitive to EGCG than the other species.
All of the species exhibited aggregation in the presence of $2 \mathrm{mg} / \mathrm{mL}$ EGCG for $1 \mathrm{~h}$ (Table 1 ). However, $1 \mathrm{mg} / \mathrm{mL}$ EGCG did not cause obvious cell aggregation in the $S$. salivarius suspension.

\section{Influence of Stimulated Saliva on the Antimicrobial}

Properties of EGCG

EGCG dissolved in saliva inhibited the glucose-induced reduction in $\mathrm{pH}$ seen in $S$. mutans in a similar manner to EGCG without saliva (Fig. 6a). Saliva alone also 


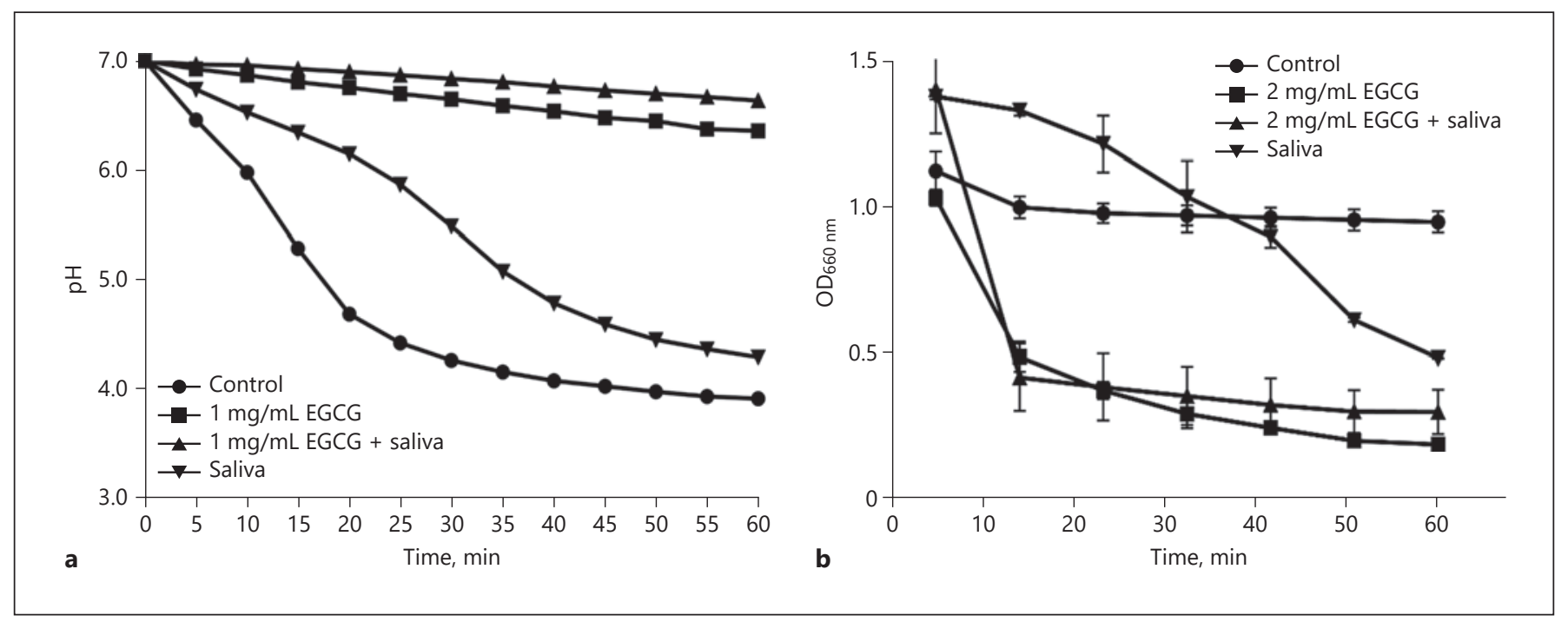

Fig. 6. Effects of EGCG dissolved in saliva on the glucose-induced pH reduction caused by S. mutans (a) and the effects of EGCG dissolved in saliva on $S$. mutans cell aggregation (b). OD, optical density.

Table 1. Acid production inhibition rates and aggregation rates of streptococcal strains in the presence of EGCG (\%)

\begin{tabular}{llll}
\hline Strain & \multirow{2}{*}{\begin{tabular}{l} 
Acid production \\
inhibition rate at \\
\cline { 3 - 4 }
\end{tabular}} & \multicolumn{2}{l}{ Aggregation rate } \\
\cline { 3 - 4 } & $1 \mathrm{mg} / \mathrm{mL}$ & & \\
& $56.3 \pm 8.28$ & $67.4 \pm 7.90$ & $78.6 \pm 1.55$ \\
S. mutans & $57.0 \pm 9.13$ & $72.0 \pm 4.80$ & $82.6 \pm 7.83$ \\
S. sanguinis & $36.4 \pm 5.88^{*}$ & $63.2 \pm 4.55$ & $77.2 \pm 9.90$ \\
S. gordonii & $58.8 \pm 6.88$ & $4.1 \pm 1.11^{*}$ & $68.3 \pm 1.01$ \\
S. salivarius & &
\end{tabular}

Data are shown as the means \pm SD of 3 independent experiments. $* p<0.05$. EGCG, epigallocatechin gallate.

slowed down the $\mathrm{pH}$ reduction caused by $S$. mutans acid production. There was no significant difference between the effects of EGCG and saliva-dissolved EGCG on bacterial aggregation (Fig. 6b). Cell aggregation was also observed in saliva alone.

\section{Discussion}

Green tea infusions and green tea extract-based beverages are the main sources of EGCG intake in daily life. Green tea-derived catechins (tea-derived polyphenols) account for $10-15 \%$ of the weight of dried green tea leaves, and EGCG accounts for 50-70\% of total catechins in green tea [Yang et al., 2009; Khan and Mukhtar, 2018; Taylor, 2020]. More than $1 \mathrm{mg} / \mathrm{mL}$ EGCG can be released into green tea infusions, which is considered to be safe [Liu et al., 2014; Dekant et al., 2017; Koch et al., 2018]. Several studies have reported that long-term tea polyphenol treatment has bactericidal effects, and the minimum inhibitory concentrations of EGCG against microbes differ depending on the measurement method, strain, culture medium, and the EGCG source [Sakanaka et al., 1989; Xu et al., 2018; Higuchi et al., 2019]. The concentrations of EGCG required to inhibit the growth or viability of oral streptococci are often in the milligram per milliliter range, but EGCG solutions with concentrations of $>5$ $\mathrm{mg} / \mathrm{mL}$ taste bitter and, thus, are not appropriate for daily use. In the present study, we showed that $0.5-2 \mathrm{mg} / \mathrm{mL}$ EGCG had no effect on the viability of $S$. mutans, except when the bacteria were subjected to 4 -h treatment with 2 $\mathrm{mg} / \mathrm{mL}$ EGCG, while 1-2 mg/mL EGCG inhibited bacterial growth (Fig. 1). These results indicated that treatment with $0.5-2 \mathrm{mg} / \mathrm{mL}$ EGCG for a short period of time, which corresponds to the conditions associated with the daily consumption of green tea, did not have bactericidal effects on S. mutans.

In the pH-stat assay, 0.5-2 mg/mL EGCG markedly reduced bacterial acid production, including the production of lactate acid, formic acid, and acetic acid (Fig. 2), indicating that at these concentrations EGCG inhibits bacterial acid production, one of the main bacterial cariogenic factors. 
No marked change in the acidic end-product profile was observed in the acidic end-product analysis, which suggests that EGCG inhibits glycolytic metabolism as a whole rather than inhibiting specific metabolic pathways, such as the branch pathways for formic or acetic acid production. Consistent with the results of the $\mathrm{pH}$ stat assay, the $\mathrm{pH}$ reduction curve was also flattened by the presence of EGCG, but it should be noted that EGCG had a marked inhibitory effect on the reduction in $\mathrm{pH}$ (Fig. 3a). The pH reduction method is influenced by various factors, such as enzyme activity under changing $\mathrm{pH}$ conditions, and the buffer capacities of the components of the reaction mixture. EGCG exhibited buffer capacity around neutral pH (Fig. 3b), which resulted in it having a marked inhibitory effect on the reduction in bacterial $\mathrm{pH}$. Taking the abovementioned results together, EGCG suppresses bacteria-induced $\mathrm{pH}$ reductions by inhibiting bacterial metabolic activity and maintains a neutral environment through its buffer capacity, rather than through bactericidal effects. In addition, the inhibition of bacterial metabolism by EGCG reduces bacterial energy production, possibly resulting in the suppression of bacterial growth.

Previous studies have shown that the suppression of acid production by EGCG can be attributed to the inhibitory effects of EGCG on lactate dehydrogenase at both the transcriptional and enzymatic levels [Hirasawa et al., 2006; Xu et al., 2011]. However, as EGCG inhibits glycolytic metabolism as a whole and is a large molecule that cannot penetrate the cell membrane efficiently, it might inhibit cell membrane-associated glycolytic enzymes rather than intracellular glycolytic enzymes such as lactate dehydrogenase [Nakayama et al., 2011, 2015]. A previous study reported that catechins can bind to lipid bilayer membranes or proteins, and since EGCG carries no charge under neutral or acidic conditions, it can readily pass through the charged cell wall and reach cell membranes [Kajiya et al., 2002; Gradisar et al., 2007]. Therefore, we examined the inhibitory effects of EGCG on a cell membrane-associated sugar uptake enzyme system, the PEP-PTS. The PEP-PTS is a group of enzymes involved in transporting sugars into bacteria, which consists of enzymes on the cell membrane and those in the cytoplasm. Our results clearly showed that PEP-PTS activity was suppressed by EGCG (Fig. 4), suggesting that EGCG inhibits the uptake of glucose into bacterial cells and, hence, suppresses bacterial metabolism and acid production. Similarly, in a study on the antibacterial effects of EGCG on Bacillus subtilis, it was found that EGCG was able to bind to several membrane proteins, including the PTS transporter subunit in the cell envelope, and reduced bacterial oxygen consumption due to glucose uptake within 30 min [Nakayama et al., 2015]. All of these observations support the concept that EGCG interacts with bacterial cell membranes and has an inhibitory effect on the PEPPTS and subsequent metabolism, and explain the hypothesis that EGCG might induce the starvation of biofilm [Maeyama et al., 2005]. In the present study, EGCG inhibited the PEP-PTS at a slower rate than it inhibited bacterial acid production (Fig. 2). This phenomenon might have been caused by the fact that PEP-PTS activity was measured after loosely bound EGCG had been removed by washing with buffer.

We also assessed the bacterial aggregation of $S$. mutans in the presence of EGCG (Fig. 5). Marked aggregation occurred within $5 \mathrm{~min}$ after the addition of EGCG, suggesting that the EGCG in green tea could reduce bacterial adherence, promote bacterial removal, and subsequently inhibit biofilm formation in the oral cavity [Liljemark et al., 1981]. The fact that the bacterial aggregation and the inhibition of acid production occurred within a short period of time demonstrated that EGCG and green tea have relatively rapid effects.

It has also been reported that EGCG can inhibit GTF activity and causes reduced biofilm formation in $S$. $m u$ tans [Hattori et al., 1990; Otake et al., 1991]. Taken together, EGCG disrupts biofilm formation through at least 3 different mechanisms, including the inhibition of bacterial growth through the inhibition of bacterial metabolism, the promotion of bacterial aggregation, and the inhibition of GTF activity. In addition, our study demonstrated that non-mutans streptococci active in the acidogenic stage of the caries process [Takahashi and Nyvad, 2008, 2011; Nyvad and Takahashi, 2020] were inhibited by EGCG. The observation that EGCG inhibited the acid production and promoted the aggregation of both mutans and non-mutans streptococci (Table 1) suggests that EGCG could be used to regulate the oral ecosystem by inhibiting acidification and accelerating the clearance of caries-associated bacteria.

It seemed that $S$. salivarius was less sensitive to EGCG than other oral streptococci in terms of aggregation, suggesting that this bacterium might possess a different adhesive mechanism from the other oral streptococci, and this might be why S. salivarius has a different habitat in the oral cavity. There was also lack of correlation between the acid production inhibition rate and the bacterial aggregation rate in the 4 streptococcal strains. These results suggested that the molecular mechanisms responsible for the inhibition of bacterial acid production and the pro- 
motion of bacterial aggregation by EGCG might be different, but further experiments are needed to confirm this.

Some studies have suggested that EGCG might react with the $\alpha$-amylase in saliva to inhibit the conversion of starch to maltose, which could have caries-preventive effects, but this binding of EGCG to $a$-amylase is likely to result in a mutual reduction in their functions [Hara et al., 2012]. It has also been reported that proteins in bacterial culture media suppress the inhibitory effects of plantderived polyphenols on bacterial growth [Xu et al., 2018]. The addition of bovine serum albumin to culture medium led to dose-dependent increases in the minimal inhibitory concentration for bacterial growth. Thus, the affinity of monomeric polyphenols for proline-rich salivary proteins in the human oral cavity is considered to diminish their antimicrobial potential [Yoo et al., 2011]. However, Figure 5 shows that EGCG dissolved in stimulated saliva still had significant effects on the bacteria-induced $\mathrm{pH}$ reduction and bacterial aggregation. In the presence of saliva alone, $\mathrm{pH}$ was slowly reduced by $S$. mutans acid production because of the buffer capacity of saliva. A similar result was observed in the bacterial aggregation assay; that is, saliva alone induced the aggregation of $S$. mutans [Gao et al., 2016]. The presence of EGCG might further strengthen the inhibitory effect of saliva on bacteria-induced $\mathrm{pH}$ reductions and accelerate bacterial aggregation in stimulated saliva, which would probably explain the ability of EGCG-containing mouth rinse to inhibit $\mathrm{pH}$ reductions in dental plaque [Hirasawa et al., 2006]. Moreover, in a randomized clinical trial, rinsing with EGCG for $1 \mathrm{~min}$ reduced the number of mutans streptococci by $79.9 \%$ and the number of lactobacilli by $72.09 \%$ in the non-stimulated saliva of children [Vilela et al., 2020]. Our findings that EGCG accelerated bacterial aggregation in saliva further suggest that the timely effect of EGCG or green tea in the oral cavity might depend on inhibition of bacterial metabolism and inducing cell aggregation. However, in vivo experiments or biofilm model experiments are still needed to confirm these properties of EGCG.

\section{Conclusion}

The current study showed that EGCG possesses buffer capacity and inhibits bacterial acid production by reducing bacterial glucose uptake (PEP-PTS activity), which together might shift the balance of demineralization and remineralization toward remineralization in the oral ecosystem. EGCG also promotes the aggregation of plaqueforming streptococci, which might help to accelerate salivary bacterial removal and reduce bacterial amount. These properties of short-term EGCG treatment were not affected by stimulated saliva, suggesting that EGCG could function in the oral cavity.

\section{Statement of Ethics}

This study was approved by the Research Ethics Committee of Tohoku University Graduate School of Dentistry (approval No.: 2018-3-17) and carried out in accordance with relevant guidelines and regulations.

\section{Conflict of Interest Statement}

The authors declare no conflict of interest.

\section{Funding Sources}

This study was supported in part by Grants-in-Aid for Scientific Research B (60183852) and Grants-in-Aid for Scientific Research C (16K11540) from the Japan Society for the Promotion of Science, and the FUTOKU Foundation from Lion Co.

\section{Author Contributions}

All authors contributed to the present study. S.H. performed the study and drafted the manuscript. Y.A. and J.W. designed the study and assisted in data analysis. Y.L. participated in data curation. L.Z. assisted in designing the experiment and provided the resources. N.T. participated in project administration, conceptualization, supervision, methodology and critically reviewed the manuscript.

\section{References}

EGCG Inhibits Acid Production and

Promotes Aggregation
Dekant W, Fujii K, Shibata E, Morita O, Shimotoyodome A. Safety assessment of green tea based beverages and dried green tea extracts as nutritional supplements. Toxicol Lett. 2017 Aug;277:104-8.

Ferrazzano GF, Roberto L, Amato I, Cantile T, Sangianantoni G, Ingenito A. Antimicrobial properties of green tea extract against cariogenic microflora: an in vivo study. J Med Food. 2011 Sep;14(9):907-11.
Gao X, Jiang S, Koh D, Hsu CY. Salivary biomarkers for dental caries. Periodontol 2000. 2016 Feb;70(1):128-41.

Gradisar H, Pristovsek P, Plaper A, Jerala R. Green tea catechins inhibit bacterial DNA gyrase by interaction with its ATP binding site. J Med Chem. 2007 Jan;50(2):264-71.

Hamilton-Miller JM. Anti-cariogenic properties of tea (Camellia sinensis). J Med Microbiol. 2001 Apr;50(4):299-302. 
Hara K, Ohara M, Hayashi I, Hino T, Nishimura $\mathrm{R}$, Iwasaki $\mathrm{Y}$, et al. The green tea polyphenol (-)-epigallocatechin gallate precipitates salivary proteins including alpha-amylase: biochemical implications for oral health. Eur J Oral Sci. 2012 Apr;120(2):132-9.

Hattori M, Kusumoto IT, Namba T, Ishigami T, Hara Y. Effect of tea polyphenols on glucan synthesis by glucosyltransferase from Streptococcus mutans. Chem Pharm Bull (Tokyo). 1990 Mar;38(3):717-20.

Hengge R. Targeting Bacterial Biofilms by the Green Tea Polyphenol EGCG. Molecules. 2019 Jun;24(13):E2403.

Higuchi T, Suzuki N, Nakaya S, Omagari S, Yoneda M, Hanioka T, et al. Effects of Lactobacillus salivarius WB21 combined with green tea catechins on dental caries, periodontitis, and oral malodor. Arch Oral Biol. 2019 Feb;98:243-7.

Hirasawa M, Takada K, Otake S. Inhibition of acid production in dental plaque bacteria by green tea catechins. Caries Res. 2006;40(3):265-70.

Ikigai H, Nakae T, Hara Y, Shimamura T. Bactericidal catechins damage the lipid bilayer. Biochim Biophys Acta.1993 Apr;1147(1):1326.

Iwami Y, Yamada T. Regulation of glycolytic rate in Streptococcus sanguis grown under glucose-limited and glucose-excess conditions in a chemostat. Infect Immun. 1985 Nov;50(2):378-81.

Kajiya K, Kumazawa S, Nakayama T. Effects of external factors on the interaction of tea catechins with lipid bilayers. Biosci Biotechnol Biochem. 2002 Nov;66(11):2330-5.

Khan N, Mukhtar H. Tea Polyphenols in Promotion of Human Health. Nutrients. 2018 Dec;11(1):E39.

Koch W, Kukula-Koch W, Komsta E, Marzec Z, Szwerc W, Głowniak K. Green Tea Quality Evaluation Based on Its Catechins and Metals Composition in Combination with Chemometric Analysis. Molecules. 2018 Jul;23(7): E1689.

Liljemark WF, Bloomquist CG, Germaine GR. Effect of bacterial aggregation on the adherence of oral streptococci to hydroxyapatite. Infect Immun. 1981 Mar;31(3):935-41.

Liu CM, Chen CY, Lin YW. Estimation of tea catechin levels using micellar electrokinetic chromatography: a quantitative approach. Food Chem. 2014 May;150:145-50.
Maeyama R, Kwon IK, Mizunoe Y, Anderson JM, Tanaka M, Matsuda T. Novel bactericidal surface: catechin-loaded surface-erodible polymer prevents biofilm formation. J Biomed Mater Res A. 2005 Oct;75(1):146-55.

Manome A, Abiko Y, Kawashima J, Washio J, Fukumoto S, Takahashi N. Acidogenic potential of oral bifidobacterium and its high fluoride tolerance. Front Microbiol.2019 May;10:1099.

Nakayama M, Shigemune N, Tsugukuni T, Tokuda H, Miyamoto T. Difference of EGCg adhesion on cell surface between Staphylococcus aureus and Escherichia coli visualized by electron microscopy after novel indirect staining with cerium chloride. J Microbiol Methods. $2011 \mathrm{Jul} ; 86(1): 97-103$.

Nakayama M, Shimatani K, Ozawa T, Shigemune N, Tomiyama D, Yui K, et al. Mechanism for the antibacterial action of epigallocatechin gallate (EGCg) on Bacillus subtilis. Biosci Biotechnol Biochem. 2015;79(5):845-54.

Norimatsu Y, Kawashima J, Takano-Yamamoto $\mathrm{T}$, Takahashi N. Nitrogenous compounds stimulate glucose-derived acid production by oral Streptococcus and Actinomyces. Microbiol Immunol. 2015 Sep;59(9):501-6.

Nyvad B, Takahashi N. Integrated hypothesis of dental caries and periodontal diseases. J Oral Microbiol. 2020 Jan;12(1):1710953.

Otake S, Makimura M, Kuroki T, Nishihara Y, Hirasawa $\mathrm{M}$. Anticaries effects of polyphenolic compounds from Japanese green tea. Caries Res. 1991;25(6):438-43.

Reygaert WC. The antimicrobial possibilities of green tea. Front Microbiol. 2014 Aug;5:434.

Sakanaka S, Kim M, Taniguchi M, Yamamoto T. Antibacterial substances in Japanese green tea extract against Streptococcus mutans, a cariogenic bacterium. Agric Biol Chem. 1989;53(9):2307-11.

Sasaki H, Matsumoto M, Tanaka T, Maeda M, Nakai M, Hamada S, et al. Antibacterial activity of polyphenol components in oolong tea extract against Streptococcus mutans. Caries Res. 2004 Jan-Feb;38(1):2-8.

Segura-Egea JJ, Gould K, Şen BH, Jonasson P, Cotti E, Mazzoni A, et al. Antibiotics in endodontics: a review. Int Endod J. 2017 Dec;50(12):1169-84.
Singh BN, Shankar S, Srivastava RK. Green tea catechin, epigallocatechin-3-gallate (EGCG): mechanisms, perspectives and clinical applications. Biochem Pharmacol. 2011 Dec;82(12):1807-21.

Takahashi N, Abbe K, Takahashi-Abbe S, Yamada T. Oxygen sensitivity of sugar metabolism and interconversion of pyruvate formate-lyase in intact cells of Streptococcus mutans and Streptococcus sanguis. Infect Immun. 1987 Mar;55(3):652-6.

Takahashi N, Nyvad B. Caries ecology revisited microbial dynamics and the caries process. Caries Res. 2008;42(6):409-18.

Takahashi N, Nyvad B. The role of bacteria in the caries process: ecological perspectives. J Dent Res. 2011 Mar;90(3):294-303.

Taylor PW. Interactions of tea-derived catechin gallates with bacterial pathogens. Molecules. 2020 Apr;25(8):E1986.

Vilela MM, Salvador SL, Teixeira IG, Del Arco MC, De Rossi A. Efficacy of green tea and its extract, epigallocatechin-3-gallate, in the reduction of cariogenic microbiota in children: a randomized clinical trial. Arch Oral Biol. 2020 Jun;114:104727.

Wang Y, Ho CT. Polyphenolic chemistry of tea and coffee: a century of progress. J Agric Food Chem. 2009 Sep;57(18):8109-14.

$\mathrm{Xu}$ X, Ou ZM, Wu CD. Growth media affect assessment of antimicrobial activity of plantderived polyphenols. BioMed Res Int. 2018 May;2018:8308640.

Xu X, Zhou XD, Wu CD. The tea catechin epigallocatechin gallate suppresses cariogenic virulence factors of Streptococcus mutans. Antimicrob Agents Chemother. 2011 Mar;55(3):1229-36.

Xu X, Zhou XD, Wu CD. Tea catechin epigallocatechin gallate inhibits Streptococcus mutans biofilm formation by suppressing gtf genes. Arch Oral Biol. 2012 Jun;57(6):678-83.

Yang CS, Wang X, Lu G, Picinich SC. Cancer prevention by tea: animal studies, molecular mechanisms and human relevance. Nat Rev Cancer. 2009 Jun;9(6):429-39.

Yoo S, Murata RM, Duarte S. Antimicrobial traits of tea- and cranberry-derived polyphenols against Streptococcus mutans. Caries Res. 2011;45(4):327-35.

Yu H, Oho T, Xu LX. Effects of several tea components on acid resistance of human tooth enamel. J Dent. 1995 Apr;23(2):101-5. 